\title{
Reclaiming the land: belonging, landscape, and in situ displacement on the plain of Karditsa (Greece)
}

Huw Halstead

\begin{tabular}{|l|l|}
\hline Date of deposit & 05122019 \\
\hline Document version & Author's accepted manuscript \\
\hline Access rights & $\begin{array}{l}\text { Copyright (C) 2019 Informa UK Limited, trading as Taylor \& } \\
\text { Francis Group. This work has been made available online in } \\
\text { accordance with publisher policies or with permission. Permission } \\
\text { for further reuse of this content should be sought from the } \\
\text { publisher or the rights holder. This is the author created accepted } \\
\text { manuscript following peer review and may differ slightly from the } \\
\text { final published version. }\end{array}$ \\
\hline $\begin{array}{l}\text { Citation for } \\
\text { published version }\end{array}$ & $\begin{array}{l}\text { Halstead, H 2019, 'Reclaiming the land: belonging, landscape, } \\
\text { and in situ displacement on the plain of Karditsa (Greece)', } \\
\text { History and Anthropology, vol. Latest Articles. }\end{array}$ \\
\hline $\begin{array}{l}\text { Link to published } \\
\text { version }\end{array}$ & \begin{tabular}{l} 
https://doi.org/10.1080/02757206.2019.1696325 \\
\hline
\end{tabular}
\end{tabular}

Full metadata for this item is available in St Andrews Research

Repository at: https://research-repository.st-andrews.ac.uk/

\begin{tabular}{l|l|l|} 
University of & FOUNDED \\
St Andrews & 1413
\end{tabular}




\section{Reclaiming the Land: Belonging, Landscape, and In Situ Displacement on the Plain of Karditsa (Greece).}

Abstract: Land reform on the Karditsa plain in the late 1960s/early 1970s greatly alleviated poverty for local farmers, but also disrupted their traditional way of life and relationship with the landscape. This in situ displacement arises not from reactionary nostalgia but from rupture to inhabitants' corporeal and sensory experience of place.

Keywords: agricultural change; in situ displacement; land reform; landscape; sensory memory; Thessaly

As a child of 10 in the early 1970s, Kostas from Pródromos in the plain of Karditsa (Thessaly) is making the journey to work in one of his father's fields by cart, faithfully conveyed, as on countless previous occasions, by the family horse. En route, disaster almost strikes. The horse abruptly departs from the track and makes headlong for a large ditch, seemingly oblivious to the impending danger. Kostas - just a child, remember - struggles to get the horse back under control. He pulls, and fights, and shouts, and, finally, convinces his horse to alter its course, just before boy, animal, and cart plummet into the ditch.

So what happened? Had the horse taken a sudden dislike to Kostas? Perhaps not. Shortly before this story takes place, the landscape around Pródromos had undergone major and rapid transformation. The Greek state undertook an extensive land redistribution and reclamation scheme (known in Greek as the anadasmós ${ }^{1}$ ) to prepare the area for intensive and irrigated farming, which involved the complete spatial reorganisation of field, road, and river systems, the draining of wetlands, and widespread levelling of the land and filling of topographic depressions. Kostas' horse, a veteran of the old landscape, knew by heart the old route from the family home to the fields and was determined to follow it, even though the path no longer 
existed and had been bisected by irrigation channels like the one into which the horse attempted to deposit young Kostas.

The changes to the local landscape were deeply disorientating not only to the animals, but also to the human population of the Karditsa plain. Local residents were not forced to relocate by the anadasmós - in fact the internal spatial layout of their villages remained mostly unaffected - but they did experience within a relatively short time frame significant changes to their natural and cultural landscape and to the markers of everyday familiarity: the faces, the food, the landmarks, the smells, routes walked daily, and fields worked for a lifetime. This resulted both in initial spatial disorientation and a longer-term sense of "un-homing" (Atkinson 2015, 376). My ethnographic research in the area confirms that people can in this way experience in situ displacement (Feldman, Geisler, and Silberling 2003). I also demonstrate, however, that this in situ place loss can be a profoundly ambivalent experience for an impoverished agricultural community, when the environmental change goes hand-in-hand with economic and technological development, and when the place lost was filled not only with markers of familiarity but also those seen by the local population as denoting poverty and backwardness.

The result is a duality in local memory: a more readily accessible narrative of the anadasmós as a positive, modernising development that saved locals from poverty, tempered by a sense of loss and alienation that emerges in more intimate conversation. I join Margaret Farrar (2009) in declining to interpret this latter narrative of loss as naïve, nostalgic sentimentality in the face of progress, and instead seek to show how it arises from real, tangible changes to inhabitants' everyday bodily and sensory experiences of place. This is revealed not only in locals' narratives about the past, but also in their contemporary ways of moving through, marking, and manipulating the spaces around them. 


\section{In Situ Displacement}

In human geography, a distinction is made between space and place. Whilst space, in Edward Casey's $(2001,683)$ words, is simply “the encompassing volumetric void in which things (including human beings) are positioned", places are products of human interactions with particular spaces and their ascription of meaning to them (Cresswell 2004, 7-11). When different places are socially and culturally knitted together through human experience and activity, we get a landscape, which is not simply an inert visual backdrop to human life (Forbes 2007, 5, 35, 395; Miles-Watson et al. 2015, 2; Tilley 1994, 23-26), but rather, after Christopher Tilley $(1994,34)$, refers to "a set of relational places linked by paths, movements and narratives".

Recent decades have also seen a "spatial turn" in the historical and social scientific literature (Alcalde 2018, 554; Schlögel 2016, xx; White 2010, 1), strongly influenced by the work of Henri Lefebvre and Michel de Certeau. Confusingly, de Certeau $(1984,117)$ inverts the space/place distinction described above, treating "place" as the static positioning of things and "space" as the dynamic realm created by human action. Lefebvre ([1974](1991), 1-2, 26, 48) similarly wrote that space is not simply "empty area" - he called this "absolute space" - but is rather socially produced, what he called "social space". "Social space" maps very closely onto the notion of "place" in human geography (Cresswell 2004, 10).

In spite of this distinction between the positioning of things in abstract (or absolute) space and the meaningful place (or social space) created by human experience, there has sometimes been a tendency within academia and policy to associate place loss with spatial dislocation: that is, 
to treat loss of place as occurring only or primarily when people are physically displaced from a point of origin (Davidson 2009; Feldman and Geisler 2012, 974; Feldman, Geisler, and Silberling 2003; Hummon 1992). Yet there are excellent reasons to challenge this association. Anthropological, geographical, and historical studies have demonstrated that people habitually enculturate their local environments by assigning meaning to potentially "perishable" features of their natural and built landscapes: be they trees, streams, fields, paths, houses, places of worship, or ancient settlements (Confino 1997; Cosgrove, Roscoe, and Rycroft 1996; Forbes 2007; P. Halstead 2014, 343; Lekan 2004; Nixon 2006; Riley 1992; Sooväli-Sepping et al. 2015; Seremetakis 1994a, 1994b; Tilley 1994, 2006). In Hamish Forbes' (2007, 7) terms, landscapes are filled with "prompts" triggering memories and connecting individuals both vertically to ancestors and descendants and horizontally to their kin and other contemporaries. It is reasonable to suspect that when these landscape prompts are threatened or eroded so is people's sense of place.

Indeed, several studies have demonstrated that, in Mark Davidson's (2009, 228) words, "[p]eople can be displaced - unable to (re)construct place - without spatial dislocation, just as much as they can with spatial dislocation". Take the aftermath of natural disasters. In 1974, a devastating tornado hit the city of Xenia (Ohio), redrawing a huge portion of the city's urban geography in just three minutes (Francaviglia 1978, 16-18). Local government and town planners resolved to use the disaster as an opportunity to correct perceived mistakes in the town's urban layout, and produced an extensive strategy to remodel the city in terms of architecture, land use, and green spaces (16-18). Local residents, however, pushed strongly and successfully "to rebuild their city as they knew it - with all its liabilities as well as its assets" (21). City residents maintained a strong emotional connection to Xenia's urban landscape and their ways of moving through it. In Francaviglia's (23-24) words, "[e]ven though numerous 
visible elements disappeared, parcels of land - rather than three dimensional scenery continue[d] to evoke emotive responses", triggering an intensification of what Francaviglia calls "nostalgia" for the "olden days" of the city as a form of "compensation for the removal of so much of the familiar, historic landscape". More recently, Farrar (2009) has similarly explored how residents of New Orleans in the wake of Hurricane Katrina experienced not only major material loss but also an "ephemeral sense of something gone missing", of being "out of place". Seeking to move away from a tendency to see attachment to lost places as necessarily nostalgic in a sentimentalist or regressive sense (see also Seremetakis 1994a, 4), Farrar conceptualises place loss as a corporeal experience, a feeling of alienation and homesickness caused by major disruption to "bodily memory of place".

Urban geographers working on gentrification have made similar findings. Traditionally, in academic literature and public policy, the focus fell on whether gentrification causes the physical displacement of low-income residents through economically driven out-migration, leading to policies such as rent control designed to allow residents to remain in situ in gentrifying neighbourhoods (Davidson 2009, 221-223, 225). This view has recently been challenged (Atkinson 2015, 377, 384-385; Davidson 2009, 223-225; Shaw and Hagemans 2015, 339). Kate Shaw and Iris Hagemans (2015), for instance, used interviews with local residents in gentrifying Melbourne neighbourhoods to demonstrate that loss of familiar aspects of the urban landscape can provoke sentiments of alienation and place loss. Interviewees pointed first to the closure of local shops, eateries, and drinking establishments and their replacement with boutique, high-end, and expensive equivalents, and second to the disappearance of familiar neighbourhood faces or "public characters" such as drug users, prostitutes, and homeless people, seen by city authorities as compromising local safety but by many long-term residents as a source of familiarity and, therefore, associated with feelings of 
greater safety. As Shaw and Hagemans $(2015,337)$ note, a significant side-effect of the "deconcentration of poverty" may be the "deconcentration of the familiar" for long-term residents.

As in the present article, changes in rural land use are another major cause of in situ displacement. In Bangladesh, land grabs by economic elites have physically displaced some peasant farmers, but have also eroded the resource base of others, who remain in situ but precariously so (Feldman and Geisler 2012, 972). In the Vietnamese Central Highlands, land reform and rapid growth in coffee production have undermined the self-sufficiency, ontological security, and way of life of the native Ede, whose relationship to the land is not easily reconcilable to the diktats of state market-oriented cultivation policy (Doutriaux, Geisler, and Shively 2008). More broadly, a special collection of social science papers considers causes as varied as the implementation of mega-projects, the proliferation of casinos on Native American land, and nature conservation projects (Feldman, Geisler, and Silberling 2003); whilst a recent volume on "ruptured landscapes" contains examples of in situ rupture - though not framed in these terms - caused by conflict, political change, environmental change, and (de)industrialisation (Sooväli-Sepping et al. 2015).

In each of these cases, local residents experienced marked disruption to their sense of place even as they remained in the same physical location. Though there are significant differences, there are also instructive parallels with the plain of Karditsa. Here too, local residents often express a diffuse sense of "something gone missing" in the wake of the anadasmós. As in Melbourne, a reduction in poverty was accompanied by an assault on the familiar. And like the residents of post-disaster Xenia, the inhabitants of the Karditsa plain employ various strategies of emplacement in an effort to make the landscape familiar once more. 


\section{The Anadasmós}

The study area for my research comprised six principal villages on the plain of Karditsa around which the anadasmós was undertaken (in stages) in the late 1960s and early 1970s (see Table 1). The residents of five of these villages identify themselves as "Karagkoúnides", an identity that marks them out as "natives" (dópioi) of the region, which in the Greek context implies a distinction from the Greek refugees who arrived from Asia Minor in the 1920s. The final study village - Kapadokikó - was founded by Greek refugees from Cappadocia, and its contemporary inhabitants call themselves "Cappadocians" or "refugees".

\section{[Insert Table 1]}

In 2018, I spent time in these villages conducting what the archaeologist Bill Alexander terms "ethnokafenology" (quoted in P. Halstead 1989, 853); that is, making a beeline for the village kafeneio (or café) and chatting with the village's most elderly residents. I followed up on these encounters - which often involved a shifting array of participants and exposed multiple, sometimes competing perspectives - with (slightly) more formal and (significantly) more focused oral history interviews with individuals or, occasionally, pairs of people. This allowed for more in-depth exploration of personal responses to historical and spatial change, and increased the number of female informants, who are less frequently found in the kafeneia. These interviews sometimes took place in people's homes and sometimes in public establishments, but also, as this is a working agricultural community, in people's fields, by the side of the road, and, on multiple occasions, whilst trailing flocks of sheep around the outskirts of villages. I also prevailed upon some informants to take me on ethnographic field walks, 
exploring the post-anadasmós spatial layout of fields and roads, and attempting to reconstruct their more traditional ways of navigating their locality. These encounters revealed interesting narratives about place that would not have emerged in the course of a static discussion.

The cultivable land in nineteenth-century Thessaly was overwhelmingly dominated by large agricultural estates (tsiflikia) privately owned by Ottoman landlords (tsiflikádes) and worked by landless peasants (koligoi) who under Ottoman law had the right to farm their parcel of land for life and to pass this right onto their descendants. When Thessaly was ceded to the Greek state in 1881, the tsiflikádes sold their estates to Greek landowners, and under Greek law the koligoi lost their rights to the land, effectively becoming regular tenant farmers who could be evicted by landlords at the end of their leases and who lost all claim to ownership over their houses, storerooms, animals, and tools. The resulting deterioration in the farmers' conditions and status spawned an organised movement of farmers calling for the state to expropriate and then redistribute the tsiflikia. After some abortive attempts to address the issue in the late nineteenth century - and after the violent suppression of a March 1910 rally left several farmers dead - reform efforts began in earnest under Eleftherios Venizelos in 1911, but were slowed by Greek involvement in the Balkan Wars, the First World War, and the Greek-Turkish War. Finally, faced with the need to resettle the Greek refugees displaced after the conflict with Turkey, the Greek state forcibly purchased huge tracts of private land in Thessaly and redistributed it to landless small-scale farmers (from both the local population and the incoming refugee communities) (Patronis 2015, 95-112).

The plain of Karditsa in Western Thessaly was in the mid-twentieth century a floodplain characterised, like much of the rest of the region, by difficult agricultural conditions. The breakup of the tsiflikia into smaller landholdings and subsequent subdivision of the latter through 
inheritance, with each new household typically receiving some land from the husband's parents and some (as dowry) from the wife's, created a fragmented field system in which each farmer worked several small parcels of land scattered across the landscape. The small size and dispersal of individual fields inhibited mechanisation and modernisation of agriculture, and led to reduced economies of scale. Poor drainage impeded cultivation and caused localised crop failures, whilst the terrain (though some of the flattest in Greece, hence the poor drainage) was not flat enough for the introduction of flood irrigation. Prior to the anadasmós, most of the farmers in the area cultivated some combination of wheat, oats, millet, sesame, various pulses, and a local variety of maize, as well as rearing sheep and sometimes cattle. Farm work was done by hand and plough animals, and villagers traversed the landscape by foot or by horse and cart through dirt tracks and across muddy terrain. With the exception of a few larger producers, most of the local farmers were engaged primarily in subsistence agriculture. The farmers were poor, and both economically and technologically lagged behind many other rural areas in Greece.

This was the backdrop for the Greek state's land redistribution and reclamation project. The work was undertaken during the 1967-1974 Greek military dictatorship, but had its roots in earlier land reform and water management projects beginning in the 1880 s with the draining of Lake Kopaiis, and intensifying after the Second World War when the state made sustained efforts to combat field fragmentation and to modernise agriculture (Idol 2018, 76; Markopoulou and Kominos 2010; Rokkos 1994). The aim was to enable the cultivation of lucrative cash crops on the Karditsa plain (Krahtopoulou et al. in press; Orengo et al. 2015, 101). After the Ministry of Agriculture had announced its intentions, a vote was held in the villages to decide whether the anadasmós should take place there, and in each of the study villages the required majority of voters supported the work. ${ }^{2}$ Those who were present at the 
time report that the vote was conducted variably through a show of hands, a voice vote, or the collection of signatures, and that only male heads of household had the right to vote. Subsequently committees formed of state agronomists and, according to local testimony, knowledgeable village elders assigned values to the existing fields based on their perceived productivity, dividing them into alpha, beta, and gamma categories (alpha being the best; gamma being primarily uncultivated lands, many of which had previously been used exclusively for grazing). The existing field ownership system was then dissolved, and farmers were issued new fields by a public drawing of lots. ${ }^{3}$ Each household received more or less the same acreage as they had owned before, but adjusted up or down according to the category of the fields, and consolidated in one or two lots rather than six or seven as previously. ${ }^{4}$

Massive reclamation works followed the allocation of fields: drainage of wetlands, redirection of rivers and elimination of streams and bridges, the installation of irrigation channels, the levelling of uneven land to enable flood irrigation, and the redirecting of roads and streams to accommodate the new field layout. This involved the destruction of major topographical features, including archaeological tombs and habitation mounds (known locally as magoúles), which - in a flat landscape - were major landmarks used for orientation (Krahtopoulou et al. in press; Orengo et al. 2015, 101; see Figure 1). One local landmark was exempted from the reclamation work: "The Eye” (To Máti), a bog endowed in local folklore with magical healing properties (Kliafa 2006; Krahtopoulou et al. in press; see Figure 2).

\section{[Insert Figure 1; insert Figure 2]}

The anadasmós significantly affected the local economy and society in the years that followed. The consolidation of the fields greatly improved economies of scale, and together with 
drainage, levelling, and irrigation facilitated mechanisation and the intensive farming of new cash crops through state contracts, particularly cotton and a new and more productive variety of maize. These changes encouraged the introduction of chemical fertilisers and pesticides, further increasing farmers' yields. There was a parallel reduction in livestock numbers, because new intensive cash crops took over grazing land and monopolised farmers' labour. Consequently, subsistence farming gave way to market-oriented farming, and most farmers saw their economic fortunes improve whilst the physical strain on their bodies lessened. Yet much was also lost: the familiar way of life that the landscape supported; old cultigens, established risk management strategies, and traditional means of food production and consumption; and much of the area's archaeological, cultural, and natural features, including valued flora and fauna (P. Halstead in press; Krahtopoulou et al. in press; Markopoulou and Kominos 2010; Orengo et al. 2015, 101).

\section{Unknown Earth}

\section{Initial Disorientation}

The anadasmós drastically redrew the topography of the Karditsa plain in a short space of time. Gone were familiar landmarks and routes and with them learned ways of orientating oneself in the landscape. The initial disorientation that this caused is captured in the testimony of Thomas from the village Myrini, who was a young man away on military service when the anadasmós took place around his village. He returned on leave one evening in the midst of the reclamation work. Arriving in the nearby city Karditsa by train, he resolved to take a taxi back to his village, theoretically a straightforward journey. The local taxi drivers, however, were reluctant to transport Thomas, for reasons that at the time were obscure to him but, in retrospect, had to do 
with the fact that the old roads had been made impassable by the introduction of irrigation channels. Finally, one taxi driver agreed to take him to the outskirts of Myrini, on the condition that he walk the rest of the way. The taxi set off, taking an unfamiliar, roundabout route through Pródromos. I will allow Thomas to take up the story:

We leave Pródromos. I'm looking around. It's night. I say to myself, “where are we going? Is he taking me somewhere to kill me?! What's going on? What have I got myself involved in tonight?” I look to the right. I look to the left. [I recognise] nothing [...] He takes me, slowly slowly, to that rise there [near the entrance to the village]. And he says, "I will leave you here" [...] I hoisted my bag onto my back, I walk, bent over double. I recognise one or two houses. [But] I could not find my house! I said to myself, "which house is it? What is going on here?" The central entrance to the village had changed, the road had changed $[\ldots]$

I get up the next day [... and] I search around the area, to go to the fields, to try to find where the fields were, to orientate myself, where was that place, where was the skisméni magoúla [one of the archaeological mounds] as we called it. Because it wasn't just that they changed the roads, afterwards the machines came in and they levelled the fields. In some places they raised them, in some places they lowered them, and you could not orientate yourself $[\ldots]$ "Where were our fields?" I say [...] "Where were those bridges that we had?" And my father told me, and I went out, to try to orientate myself, to remember the way things were. It was as though I had come down from another planet!

Thomas experienced an uncanny encounter with place in which the familiarity of certain landmarks - particular houses that he recognised, other villages - accentuated the strangeness 
of his inability to find other points of reference - notably the family fields, the archaeological mounds, and his own house. His feelings of place alienation are not the product of a nostalgic attachment to the status quo, but rather, following Farrar (2009), result from physical disruption to the "intersection of place and body" that makes spaces familiar. "Our bodies", Farrar suggests, "know the difference between old place and new: we negotiate familiar surroundings with ease and comfort (a long stride, a confident gaze), and unfamiliar ones with anxiety and distress (hurried steps, darting eyes, sweaty palms)". We see this clearly in Thomas' narrative: in his glancing this way and that, his monologued rhetorical questions, his frantic traversing of the land and interrogating of relatives in an effort to make his surroundings familiar once more. Other informants echoed Thomas' experiences: one resident of Makrychóri, for instance, remarked that after the work it was "very strange, you left the village and everything had changed".

Nevertheless, what stands out even more in informants' narratives about the aftermath of the anadasmós is the difficulties caused by the acquisition of new, unfamiliar land. Although all of the villages in my study area voted in favour of the land reform, there were significant anxieties, disagreements, and some voices of opposition. Some farmers were immediately in favour, having learned from the Ministry of Agriculture, the residents of other villages, or firsthand experience as hired labourers in other regions what the economic benefits would be. ${ }^{5}$ Others were concerned, fearing that they would lose existing fields that they considered to be of good quality, or where they had constructed something of material value like a storehouse or a sheep pen, and, through the luck of the draw, end up with less valuable fields. Farmers who possessed large herds were afraid that grazing land would be lost, and particularly that communal land near the villages set aside for grazing plough animals - the zevgarolivado would be converted to private arable land (as indeed frequently happened). ${ }^{6}$ 
To offset these risks, many farmers took advantage of the ability to express a preference for the category of fields they would receive in the public drawing of lots. The grading of the fields took place before any reclamation work was done, and took no account of distance from the village, so simply choosing a higher grade was no guarantee of success. Charalampos from Pródromos recalled that whilst some villagers took all beta category so that their fields might fall in a single place, his father elected to take half alpha and half beta, which would necessitate the new fields falling in two different places, but reduced the risk of landing up in an undesirable area. In Karditsomágoula, meanwhile, most villagers were reluctant to take advantage of an offer to have their new fields in a gamma category area near the village - in spite of the lures of proximity and greater acreage - on the basis that those fields were considered to have poor fertility. This evidence supports Paul Halstead's (2014, 201, 338-339, 345) view that in spite of having little formal education traditional Greek farmers were "rational decision-makers" who intimately understood and actively made multifaceted cost-benefit choices.

Once lots were drawn, families set off to inspect their new land. Their trepidation is evident in their oral testimonies today: as I was told on multiple occasions, they were heading into “unknown earth”. Outside Karditsomágoula, Barba Kostas recalled his consternation when he visited his new fields for the first time. The soil quality was poor, and his plot was bisected by an old trench, making it difficult to cultivate efficiently. He knew straightaway that he had not had good fortune. "We landed up in black earth," he remembered saying, "bad news. Here we will catch the devil [i.e. it is diabolically bad luck]". Barba Kostas was fortunate - as he stood contemplating his predicament, news arrived that the acreage that constituted his wife's dowry 
had (unusually) been allotted separately and was alpha category, ready for cultivation - but the memory of this initial fear has stuck with him.

Theano - a 70-year-old woman from Agios Theódoros who has handwritten several invaluable yet unpublished tomes filled with local folklore, history, and autobiographical tales - had a similar story to tell about her first encounter with the fields assigned to her family, which had been drawn out of the hat by a family member as both she and her husband were absent at the time. The new land fell in two different places, but in both cases on arrival Theano found a waterlogged pit in the middle of the field, and no buildings or other immovable property that would compensate for this defect. It was, as she put it, "shapeless. It wasn't a field, it was a bog. 'My oh my, how can we come here?' [I said]. In the beginning we did not like the place at all". After considerable toil, the fields were made workable, and for Theano it is a point of pride that a contemporary visitor would never know what the fields used to look like. Looking back on the incident now, she observed wryly, "we should have picked someone luckier [to do the drawing of the lots]!"

What these stories reveal is that landscape change can provoke sentiments not altogether dissimilar to those caused by physical displacement: namely a sense of unease and ontological insecurity arising from disruption to place familiarity. Even if previously owned fields were difficult to work and scattered across the landscape, they were a known quantity, handed down from a previous generation, earth from which farmers knew they could make a living, however meagre. 


\section{Family Fields}

In Methana in the Peloponnese, Forbes $(2007,203-205,324)$ found that family fields constitute “"islands' of special meaning [...] set within an undifferentiated 'sea' of others' fields", possessing not just economic but also affective value as a source of identity, self-sufficiency, and kinship and historical connections to the land. Even when no longer economically viable, Forbes' acquaintances were reluctant to allow their fields to convert to scrub or to be sold to strangers (203-204, 325-326). On the Karditsa plain, the children and grandchildren of those who were of working age when the anadasmós happened frequently impressed on me the belief that their elders had similar emotional connections to inherited family fields, and that they lamented their loss. Yet these elders themselves were generally dismissive of such suggestions, insisting that what was important to them was not particular plots of land but whether the fields were productive. As one woman from Ágios Theódoros, asked whether it upset her to lose the fields that had been her dowry, laconically put it, "earth is earth".

There are several ways in which we might account for this discrepancy. First, my elder acquaintances may not have felt comfortable revealing these kinds of emotional attachments to an outsider. Indeed, it is notable that informants were often happier to tell these sorts of stories about others than about themselves. In the café of Agios Theódoros, I had spent some time discussing the affective dimension of the loss of family fields with a group of elderly men, and was receiving the usual indifferent responses. Egged on by some of their younger companions, however, the elderly men began to recount a story about another villager who had gone to market to sell one of his oxen. This man had agreed on a price with a potential buyer, and was about to seal the deal, but first decided to ask the buyer for a cigarette. "I don't smoke", was the response of the buyer. To this, the seller abruptly turned around and said, "then I am 
not selling!" The seller's rationale was that if the buyer did not smoke that meant that he would not take breaks (to smoke) during work, which in turn meant that he would overwork the ox. The seller felt sorry for his faithful ox, and decided against the sale. In Pródromos, Petros was similarly prepared to acknowledge that "people" were "bound" to their fields "like a married couple" and were perturbed by their impending loss, but he was persistent in describing this in the third-person plural, never explicitly attributing the sentiment to himself.

Second, it may be significant that on the pre-anadasmós Karditsa plain plots of land were often changing hands anyway, albeit in a more piecemeal fashion, as parents divided pieces of their land to hand onto their sons and to provide dowries for their daughters; although, equally, such subdivision could strengthen affective ties by creating "archipelagos" of proximate plots owned by relatives, inscribing kinship relations onto the landscape (Forbes 2007, 320-322). Third, extensive first-hand experience of how hard it was to work the scattered pre-anadasmós fields by hand may well have offset any feelings of loss. The old landscape was for local farmers to a significant degree synonymous with poverty and struggle, and however much they might today lament their fields falling into disuse when there are no descendants willing or able to take them on, they are proud that the greater prosperity the anadasmós brought has enabled them to provide their children with different life opportunities and a better formal education than they had themselves. As one informant recalled, "I said to my children, 'read so as to leave the fields"'. Fourth, the fields were the farmers' only livelihood, and in this context it is hardly surprising that material rather than affective or aesthetic considerations should be in the forefront of their minds (see also Jürgenson 2015, 119, 126).

There is, however, another way of looking at this question that is not governed by a dichotomy between "rational" economic considerations and "irrational" emotional ones. In Myrini, I was 
quizzing Thomas about whether he lamented the loss of family fields, to which he was consistently responding by talking about concerns over productivity and material quality. His son Thanasis took up the challenge, trying to get his father to focus on any emotional connections. Having failed to do so, Thanasis decided to drop his dad in it: "Dad, the truth is, we have some fields [inherited] from my grandfather [...] far away. It does not suit us very well, the distance, because the cost is great. They are very good fields, and we have thought several times about selling them, and buying others nearer here. Despite that, our heart does not allow us to do it." Turning to his father, Thanasis finished, "why doesn't our heart allow it? We would make more money." Thomas responded, again, by pointing out that those fields are good quality, and that if they were not they would sell them. Thanasis demurred, saying, "I would not give them away, because they remind me of my grandfather. For that reason, and for that reason alone", to which Thomas, at length, conceded, "okay, there is also that".

It is indeed possible that Thomas is being coy in fixating on field quality, or that Thanasis is mistaken in attributing to his father an affective connection, but there is an alternative explanation that can perhaps more adequately reconcile the son's perception with the father's narrative. For the older generation, family fields may have been valued primarily for their familiarity, something which is neither narrowly economic nor narrowly affective, but rather has to do with a sense of ontological security. When the anadasmós took place, farmers experienced loss of familiarity with particular plots of land, the strengths and weaknesses of which were a known quantity. In many cases, these fields had been worked for years by the owners themselves or by their fathers(in-law) or even grandfathers, and, whatever their quality, they had worked hard to make them viable. They knew which fields could be relied upon to provide a good yield of particular crops in particular seasons/conditions, and had often increased the value of uncultivated land through the construction of immovable property. After 
the anadasmós, the farmers fell into "unknown earth", not knowing what the yield would be or what they would be able to cultivate.

In most cases, however, once the reclamation work and irrigation had been completed the new fields were significantly more productive and easier to cultivate. Even the fields that Barba Kostas had been so pessimistic about ultimately gave a very good yield, in part because they had not been exhausted through previous cultivation. Over time, by working the new fields the farmers were able to recreate a sense of place familiarity by learning what the new land could offer, and by making it productive through their own work. Thanasis reckons that over the years his father Thomas has become emotionally connected to his new fields, which he has worked to the point of familiarity and, therefore, reliability. The process has now come full circle: Thanasis is currently trying to exchange some of this land to consolidate their holdings, ${ }^{7}$ but has found Thomas resistant, the latter often weighing in to say, "are you really going to give away that field, which is good, which is our field?"

In Pýrgos Kieríou, 79-year-old Athanasios expressed a similar attachment to his new fields, which - though uncultivated - he visits on a daily basis:

The fields made me. I like to go to see them. And I might not have anything there, I might not have planted cotton or wheat or [whatever]. But I will go and see them, every day. Because I like to see them. I ached for them, I worked them, they provided for me and they fed me.

Despite this declaration, Athanasios rejected out of hand the suggestion that losing his old inherited fields in the anadasmós might have bothered him, offering the pithy retort that "a 
field is a field: whichever field is yours is the one you will work". He often passes by the location of his old fields, but, in his words, feels "nothing; simply I am happy that I have the fields that I have, that I keep them tidy, that I don't let them fill with weeds". Athanasios' yearning for his current fields derives precisely from the familiarity that comes from the daily grind of working and making a living from the land. For him and many of his contemporaries, what is important is not inherent to particular parcels of land but rather has to do with ownership of earth that, by their own hand, they can be proud of and can rely upon.

\section{The Duality of Local Memory}

Talking with people on the Karditsa plain today, the dominant message that emerges in their narratives is that the anadasmós was an overwhelmingly positive development. "It was a good thing", I was told repeatedly, "it saved us", "it was a miracle", "it was like being born again", "we left poverty and hunger behind". The more that I talked with people in the villages, however, the more it became apparent that there was a second, more critical narrative about the changes unleashed by the anadasmós, connected not in a narrow utilitarian sense to the absence of particular features of the local landscape, but rather to the local "storyscape" (Kaufman 2009), that is the stories, memories, and meanings people attach to the landscape.

\section{Story Sites and Gemeinschaft}

I first met octogenarian Pavlos in the village kafeneio of Agios Theódoros as part of a group of elder male villagers, where he joined his companions in characterising the land reform as an unqualified improvement. Over several subsequent, private conversations, however, this positive narrative - though never abandoned - was tempered by lamentations about what was 
lost. Pavlos expressed particular regret at the destruction of the "wonderful vineyards" where everyone in the village had once had a parcel of land. As Forbes $(2007,256)$ has shown, vineyards can be a powerful "prompt" in the mnemonic landscape, because they remind people both of deceased ancestors who planted and tended to the vines and jovial communal work parties at harvest time. At the time of the anadasmós, the vineyards had not been used for arable land for a long time, and so had particularly fertile soil. The village elders therefore decided that they should be reclaimed and distributed as part of the land reform. Those who were younger at the time - like Pavlos - were opposed, as they felt a strong emotional connection to the vineyards that had belonged to their forebears and wanted to preserve them, in Pavlos words, "as a memento of our grandfathers". Pavlos also spoke fondly of a small stone bridge that he used regularly en route to his mother's village Makrychóri. Bridges of this sort were a feature of the old landscape, but, after the reorganisation of the field system and the redirection or elimination of streams, often ended up marooned in the middle of someone's new fields (see Figure 3), and had to be destroyed to enable the field to be cultivated. These bridges were not only landmarks in a flat landscape but also meeting places (e.g. for courting couples), and their loss was lamented by several of my informants.

\section{[Insert Figure 3]}

As Pavlos' testimony makes clear, the disruption to place familiarity caused by the disappearance of "story sites" (Kaufman 2009) from the landscape may be particularly marked when they are connected in local inhabitants' minds with particular activities, episodes, or people. We see this, too, in relation to old family fields, which are often cognitively associated with a simpler and more harmonious way of life. Before the anadasmós, because the terrain precluded mechanisation, people out of necessity cooperated at key moments in the farming 
calendar, especially when harvesting and threshing. After the anadasmós, with the consolidation of fields and subsequent mechanisation, farm work gradually became more individual, as each family had the capacity to cultivate their fields on their own without outside help. At the same time, the increasing market orientation of cultivation bought producers into competition with one another, just as economic improvements created fertile ground for jealousy as some farmers acquired new technology faster than others.

This transition, mirrored elsewhere in Greece and across the Mediterranean (P. Halstead 2014, $110,145,174)$, gives rise today to what David Sutton $(2001,54)$ calls "narratives of gemeinschaft", that is, wistful recollections of a time when people were closer, life was simpler, and there was greater solidarity. Across the study villages, elder inhabitants' narratives were peppered with two oft-repeated assessments of life before the anadasmós: "we were poor, but we got on well"; and "life was hard, but there was no anxiety". Thanasis, reflecting on time spent listening to his parents' generation reminiscing in the village kafeneio, nicely captured this sense of lost Gemeinschaft:

I don't see them having nostalgia for the place as it was, but more so how they used to live their lives. They miss that they used to work together, to eat together, to struggle all together. The place itself, it did not have much interest for them, and it did not make them much money, so it would be very difficult for them to say they wanted to return to something like that $[\ldots]$ But I see that they tell stories about how things used to be, their grandfathers, how they all gathered together in the plateia [village square], how they used to do things, how they worked together in the fields. 
As well as the end of collaborative work, the consolidation of the fields meant that each individual bordered with fewer neighbours, and therefore had contact with fewer people on a daily basis, removing familiar faces and the calls of familiar voices from the everyday experience of the landscape. As Karditsomágoula's Barba Kostas put it, after the anadasmós, "you went out [to work] and it was like a desert, you did not see anyone". The "islands of special meaning" and kin-based "archipelagos" of land of the sort described by Forbes (2007, 203, 320) were thus replaced with a monotonous personal "desert".

\section{Tastescapes}

Before the anadasmós, locals' food had consisted primarily of home-grown produce. Afterwards, with the reduction of livestock numbers and the conversion of fields for cash crops, people began instead to buy their produce externally. Local testimony suggests that this transition was a rather ambivalent social experience, and one which may often have been welcomed. Although in Greece rural life (and food) is often portrayed as more culturally authentic, this very same rural authenticity is frequently seen as parochial and backwards, such that in rural areas "modern" foodstuffs are often positively valued (Sutton and Vournelis 2009, 164). One informant recalled that when bakery bread began to appear in the villages those who still baked bread at home - or still used cornmeal (maize flour) rather than wheat flour ${ }^{8}-$ were labelled "backwards" by some fellow villagers, exerting social pressure on them to change their food production/consumption practices.

Today, however, such traditional foods are both valued and missed, though these narratives have to be teased out. At the kafeneí in Agios Theódoros, I asked a group of elderly men whether the food they ate changed after the anadasmós. Their instinctive answer followed the 
standard narrative of economic improvement: "no", they said, "things got better, not worse". Changing tack slightly, I asked them whether the bread that they purchased from the bakery was more or less the same as home-made bread. This generated a very different reaction:

No, no. Like day and night. Back then we made sour-dough bread outside in the gástra [a kind of cooking pot]. The whole neighbourhood was fragrant from it. The bread that you buy from the bakery does not have the same taste as the home-made bread. And nor did the home-made bread have chemicals in it.

Across the villages, many lamented the demise of the old variety of maize, which had once been dominant in the region as it was able to tolerate the dry conditions, but, after the advent of flood irrigation, was supplanted by a different maize seed that, adequately watered, gave a greater yield. In Pródromos, Charalampos recalled that they used to eat bompóta (cornbread), which, he emphasised, "was back then made from the local maize." "Not," he said derisively, "that variety that we have now. That is not edible. The local one, when your wife took it out of the gástra, it was fragrant”. Barba Kostas in Karditsomágoula concurred, complaining that the maize seeds have now become crossbred, and that the crop is today contaminated with fertiliser and pesticides, spoiling the taste. These sentiments were echoed by female informants: Dimitra in Pýrgos Kieríou, for instance, spoke fondly of baking cornbread with her mother-in-law, and lamented that whilst "back then we did not put chemicals in, now chemicals are all we eat" (though both she and her husband also emphasised that baking bread in the traditional manner was a demanding and time-consuming task for women).

In a taverna in Pródromos, I asked Kostas whether, despite all the improvements, he felt that anything was lost during the anadasmós. His instinctive reply was a variation on the common 
refrain: "what did we lose?" he said, "we did not lose anything, we only gained". Later in our conversation, however, Kostas - eyes brightening, and apropos of nothing in particular spontaneously offered the following wistful recollection of the village's bostánia (gardens where melons were grown):

Where we walked today, on that road people had their bostánia. The melons gave off such an aroma, that the whole place was fragrant. The aroma was so strong that even from the road the whole place was fragrant. Because all of the fields there had melons and watermelons, which were for the house, not for selling. Now, there is nothing. But if I walk by there, I can still smell it. And there used to be colours everywhere. The wheat, the bostánia, the melons, the watermelons, the sesame, the kidney beans, everything.

Earlier in the day, as we drove and walked around the area, such moments of spatial and sensory recognition had kept coming to Kostas: where the old roads used to be, the once deep river where the villagers washed their clothes, the colours of the fields, the smell of freshly baked home-made bread. In the taverna, Nancy Krahtopoulou - archaeologist and my guide in Thessaly - recalled a recent incident that vividly illustrated this sensory intrusion of the past into the present. She and Kostas had been walking in some fields far from the village, when suddenly Kostas veered off in the direction of a particular field shouting "SAM! SAM!" After some initial confusion, it transpired that Kostas had seen a field full of sesame (sousámi in Greek, sam in the local dialect), a familiar sight before the anadasmós that reminded him of his childhood (see Figure 4). As C. Nadia Seremetakis (1994a, 8, 10-12) suggests, discarded or forgotten cultural artefacts - whether organic or inorganic - carry sensory memory with the 
capacity to enable past experience to suddenly breach the present moment. The sensory memory conjured here was visual and tactile more than gustatory or olfactory.

\section{[Insert Figure 4]}

Parallel to the reduction in livestock numbers, local farmers began to introduce foreign Dutch or German sheep into their herds, as these animals produced more milk and a greater number of lambs than the hardier local Karagkoúnika sheep (see Figure 5). This made them more suitable for a landscape with reduced space for grazing animals. However, the milk given by the new sheep breeds had a significantly lower fat content, and therefore produced a very different tasting milk and cheese. The old dairy products, informants intimated, were strong and robust in taste and smell, commensurate with the hardy animals, people, and landscape that produced them. By contrast, drinking milk from the new breed of sheep, according to one informant from Agios Theódoros, "is like drinking water". Informants held the quality of the new sheep breed's meat in equal contempt, even sometimes deriding it as "inedible". With the reduction in livestock numbers, local inhabitants increasingly got their meat from the butcher, which was likewise widely seen as comparing unfavourably to locally reared meat, partly in terms of taste but also because, as I was often told, "you do not know what you are eating" (i.e. what chemicals may have found their way into the meat). Both Charalampos from Pródromos and Theano from Agios Theódoros were vocal on this topic, explaining that the meat from the local chickens was "tough" but "tastier" and could be eaten simply stewed with vegetables, whereas store bought chicken today is "soft" and can only be eaten roasted.

\section{[Insert Figure 5]}


This is the classic "cycle of rebirth" (Di Giovine and Brulotte 2014, 18; after van Esterik 2006) whereby foods once associated with poverty or considered as starvation foods become affective heritage foods. In effect, local informants claim a distinctive terroir for the Karditsa plain whereby the taste of the food is shaped by the physicality of the landscape (Trubek 2008) and its socio-cultural patterning (Di Giovine and Brulotte 2014, 10): the crops and livestock that can tolerate a sun-drenched and poorly drained landscape; their "organic" quality derived from the prohibitive cost of chemical fertilisers; and the methods of production that brought the food to the table. The place memories that these foods evoke are multisensory, involving not just taste but also smell, sight, and touch, confirming the central role that the senses play in the construction of place and the remembrance of lost place (Seremetakis 1994a, 3-4, 8, 1994b, 28-29; Sutton 2001, 88-102).

\section{Emplacement}

As the anthropologist David Turton $(2005,278)$ notes, to study displacement without also considering emplacement is to risk reducing displaced people to passive social agents who lack the capacity to (re)produce home in new environments. Various strategies of emplacement that seek to recreate a sense of place familiarity can be detected on the Karditsa plain.

One is the persistence of local toponyms. Prior to the anadasmós, the areas surrounding each village were named after notable features of the landscape. Around Pródromos, for instance, there was kalampokés (where they used to grow kalampóki, i.e. maize), kserochórafa ("dry fields", an area with gamma category fields), magoúles (where there was an archaeological mound or magóula), and ampélia ("vineyards"); whilst around Agios Theódoros there were areas called prótes ('firsts', i.e. alpha category fields), revýthies (where revýthia or chickpeas 
were grown), triária ('triplets', an area where everyone had a plot of 0.3 ha), and bourdénia (a barren area where lots of asphodels used to grow, valued locally for medicinal reasons). In most cases, these topographic features ceased to exist after the anadasmós - some had disappeared long before - but elder residents nevertheless continue to use the same toponyms. In the words of Kostas from Karditsomágoula, "irrespective of the anadasmós, we speak the language that our grandfathers had. We have not made new names, we have the old ones". The older generation seem to have mentally mapped these areas in relation to the new landscape, and today if asked about the old toponyms will pivot on the spot and point in their direction on the horizon. Forbes (2007) demonstrated that on Methana features of the landscape serve as a cognitive historical and kinship map, such that walking through the landscape becomes, in Tilley's $(1994,27)$ terms, “biographic encounters for individuals, recalling traces of past activities and previous events". On the Karditsa plain, even when these physical features have disappeared, the persistence of place names serves to preserve this biographic topography, imposing a degree of continuity and familiarity on a changing landscape.

Other emplacement strategies are more tangible, involving various physical objects. Many local residents have held onto artefacts related to traditional agriculture and food production. At his sheepfold in Makrychóri, Kostas was reminiscing fondly about his mother's home-made bread, when he decided to show me the lamarina (the metal plate) that used to sit over the gástra (the cooking pot):

If I tell you, I have the lamarina of the gástra over there behind the [guard] dog, it hurts my heart to throw it away. I don't want to throw it away, because you don't get them anymore. Today there are no craftsmen to make them. So I kept it, and I have it over 
here. You will say to me, "what will you do with it?" I will not do anything with it. I just have it here to look at.

Kostas headed off to fetch the lamarina, only to find that it had been stolen. He was stoic about the loss, but was clearly disappointed, and spent some time trying (in vain) to track down the item. A few days later, I was able to see a lamarina in the yard of Barba Kostas in Karditsomágoula, which he too described as a "memento" that he could not bring himself to throw out (see Figure 6).

\section{[Insert Figure 6]}

Such mementos may be mostly to look at, but when the occasion arises they can also be put once again to bodily use. On one evening, I travelled to the village Kapadokikó with my father (an ethnoarchaeologist) to photograph a massive stone mortar, once used as a vessel for pounding grain to make traditional dishes, and now displayed prominently as a memento in the plateía. After visiting the mortar, we made a beeline for the village kafeneio to conduct some ethnokafenology. We mentioned our interest in the mortar, prompting the café owner to disappear into a backroom. When he reappeared a few minutes later, he was wielding two giant wooden mallets, the instruments that were once used to pound the grain in the mortar (see Figure 7). Shortly afterwards, the café owner resolved to stage a demonstration, and, after recruiting an assistant from amongst his patrons, led us outside.

\section{[Insert Figure 7]}


In the plateia, our hosts conducted a historical re-enactment of how they used to stand around the mortar, each in turn bringing the mallet over their shoulders and down onto the grain (Figure 8). As the participants recreated the bodily experience of working in a remembered and now lost landscape, they took evident pleasure and comfort in the physical familiarity and ontological ease which this act brought to them. This exceptional encounter vividly demonstrates how, in Christopher Tilley and Wayne Bennett's $(2004,9)$ terms, "places belong to our bodies and our bodies belong to these places", such that an artefact can become "continuous with the arm that grasps it" (see also Seremetakis 1994a, 11) - and, I would add, by returning to these bodily motions, we can go some way to recreating past places, even if only for an instant.

\section{[Insert Figure 8]}

Mementos can also be grown, enabling locals to combat the disappearance of familiar sights, smells, tastes, and bodily actions. Though their fields are today dominated by cash crops, many farmers continue to maintain gardens where they grow produce for the home, and assiduously avoid modern cultivation practices, working by hand and eschewing chemical fertilisers and pesticides. In Agios Theódoros, one man was lamenting that he is getting too old to tend a substantial vegetable garden, when his wife cut across to extol the virtues of pesticide-free home-grown vegetables, and to insist that she will continue to grow her own produce irrespective of age. In their fields, some people still sow a single line of the old maize seed alongside the new variety, enabling them to make traditional cornbread at home. In Pródromos, nonagenarian Charalampos conducts a related ritual. He sometimes purchases a handful of the old maize seed from a passing salesman, and grows it in the little vegetable patch that he has in the garden of his home. Asked what he planned to do with the few ears of maize he has now 
grown and harvested, he replied, "nothing, just for a memento. For memories. I have it inside [in the house]" (see Figure 9). In these cases, it is not just the consumption of the end product, but also the bodily acts of sowing, growing, and harvesting themselves that conjure up a connection to a lost place.

\section{[Insert Figure 9]}

To some extent, local residents can push back against macro-changes to traditional ways of life brought by economic and technological development by manipulating the minutiae of their own micro-worlds, be it through place naming practices, by recreating an aspect of the old environment in miniature, by affixing stories and familiarity onto new landscape features, or by holding onto - or, even, regrowing - "artefacts" that carry associations with an older landscape and an older way of life. In this way, after the land was reclaimed for modern agriculture, local residents seek wherever possible to reclaim the land as home.

\section{Conclusions}

The anadasmós on the Karditsa plain differs in significant ways from many of the other examples of in situ displacement discussed at the outset. Unlike in Xenia, New Orleans, or Melbourne, the changes that took place in Thessaly were by and large presented by local residents as overwhelmingly positive developments. There are several reasons for this. First, the land reform led to significant economic improvements for existing residents, rather than simply making the area itself more prosperous and therefore less affordable for long-term residents, as in Melbourne. Second, these improvements helped to keep people living in the local area rather than encouraging out migration of familiar faces. Prior to the land reform, 
there had been significant emigration of villagers to urban centres in Greece and abroad, but afterwards this process was partially arrested - at least in the medium-term - and some emigrants even returned to take advantage of the more conducive farming landscape. Third, in Thessaly the places of habitation - the villages themselves - were largely unchanged, providing a familiar anchor in a changing landscape. Fourth, unlike the urban workers in gentrifying Melbourne who saw their traditional workplaces and livelihoods disappear, farmers in Thessaly were more able to recreate place familiarity by working the land and thereby shaping it with new meaning. Put differently, for small-scale rural farmers, total alienation from the landscape - "placelessness" of the sort described by Edward Relph (1976) in urban environments - is simply not an option, because, as Forbes $(2007,28)$ notes, their livelihoods depend upon "an intimate knowledge of landscapes and their associated flora and fauna".

Yet, in spite of these factors, it is clear that, as in Melbourne, a "deconcentration of poverty" was accompanied by a "deconcentration of the familiar" for the residents of the Karditsa plain (Shaw and Hagemans 2015, 337). However much the old landscape was associated with poverty and gruelling hard work, its tangible and intangible features were also populated with meaning for local inhabitants, and their disappearance could result in a diffuse yet potent sense of place estrangement. This relates not so much to changes to the physicality of the landscape as to how the changed landscape in turn altered the rhythms of everyday life and its accompanying storyscape and sensescapes. The land reform caused a detectable and lasting rupture in residents' understandings of "home", where home, after Farrar (2009), is "who we are in the context of particular places $[\ldots]$ what we do in those places, and who joins us there".

Place attachment has sometimes been conceptualised as inherently reactionary and regressive, tied either to naïve nostalgia or exclusivist politics of identity. Certainly, this is sometimes the 
case. In relation to the anadasmós, however, place attachment need not be interpreted as evidence of a reactionary stance towards economic development or agricultural change, nor as a sentimental romanticisation of poverty or rural "authenticity". The villages in question voted in favour of the land reform - in some cases, they had even petitioned the state for it to happen faster - and today elder farmers are acutely aware of the ways in which it made their lives easier, and reduced the toll on their bodies. Taking my cue from Farrar, Seremetakis, and Sutton, I interpret the subsequent duality and ambivalence in local memory as a product of significant changes to the bodily and sensory experience of place: ways of moving around the landscape, its sensory prompts, and how the body is used to work the landscape in conjunction with others' bodies. It is this bodily and sensory alienation that manifests itself in inhabitants' narratives.

The concept of studying in situ displacement alongside or as well as ex situ displacement is not new (see Feldman, Geisler, and Silberling 2003). Yet a more systematic, wide-ranging, and transdisciplinary study of this phenomenon is still required. The different causes of in situ displacement that could be comparatively investigated through case studies from the past and present is extensive: gentrification; rural depopulation; land-use change (clearing, enclosure, reclamation, rewilding); natural disaster; environmental change (climate change, deforestation, flora/fauna extinction); political or ideological change; touristification; destruction of cultural heritage; linguistic change; technological change (e.g. disappearance of online communities through changes to digital platforms); even changes internal to individuals' minds (ageing, dementia, mental illness). This agenda will doubtless also require us to confront cases in which narratives of in situ displacement do function partly in regressive or exclusivist ways. Without an integrated and focused approach of this sort, there is a critical danger of continuing to underestimate how frequently place attachment is disrupted in the contemporary world, and to 
make policy mistakes by disregarding processes that cause place loss without the physical movement of a population through space.

\section{Coda}

My interlocutors on the Karditsa plain tended to adopt a tripartite periodisation when discussing their own lifetimes. "The olden days" (ta paliá ta chrónia) or "those days" (ekeína ta chrónia) covers the years before the anadasmós when life was hard but simple, followed by the postanadasmós period of comparative ease and prosperity with an undercurrent of longing for a more traditional way of life. The third and final period that features heavily in their narratives begins in around 2010, and is the time of "The Crisis". The Greek sovereign debt crisis and subsequent austerity measures have exacerbated longer-term structural weaknesses in the local smallholding economy, but perhaps what has been felt more keenly than anything by my elder informants is the necessitated return of their children from more lucrative jobs they have lost in the cities back home to the villages; back to exactly the sort of life from which their parents had worked so hard to deliver them. Some of these returnees - people like one of my informants, former builder now, in his words, "again with the animals" as a shepherd - had spent enough time working in the fields as children to have the skills and mindset to return to the land; others face the bleaker prospect of chronic unemployment.

Just as Daniel Knight (2012) has observed in an urban context elsewhere in Thessaly, people on the Karditsa plain often seek to understand and inhabit this contemporary crisis through analogic reference to the past. My informants commonly constructed the time of "The Crisis" as a return to the hardship of "the olden days", but a return made worse by the replacement of the simplicity of working one's own land for subsistence with the insecurity and anxiety of 
unemployment and/or unfavourable market conditions for agricultural produce. For the older generation who lived through the anadasmós, it was always potentially an unfortunate consequence of their success in educating and broadening the horizons of their children that their fields would fall into disuse with no one to take up their cultivation; it is a double tragedy that they should do so whilst those children languish at home in the village without the skills, or sometimes the inclination, to cultivate the fields.

Acknowledgements: This research was generously supported by the British School at Athens, where I was the Macmillan-Rodewald Postdoctoral Student in 2018. My work in Thessaly was made possible through an affiliation to the research project Long time, no see: land reclamation and the cultural record of Kambos, Western Thessaly (LTNS), led by archaeologists Nancy Krahtopoulou and Hector Orengo. The former was instrumental in bringing me to Thessaly, motivated by a desire to bring to light local stories about landscape change that had received little attention. I am indebted to my guides and companions in Thessaly, Nancy Krahtopoulou, Kostas Palaiochoritis, Paul Halstead, Stefanos Bakalis, Thomas Markinos, and Thanasis Markinos; and to the residents of Agios Theódoros, Kapadokikó, Karditsomágoula, Makrychóri, Myríni, Pródromos, and Pýrgos Kieriou, who were exceptionally hospitable and welcoming, patiently responded to my questions, and provided excellent company. Nancy Krahtopoulou kindly gave permission to reproduce figures 1 and 4. For comments and feedback on versions of this research, I thank the anonymous reviewers of History \& Anthropology, Nancy Krahtopoulou, Paul Halstead, and the audiences at the British School at Athens, the Institute for the Public Understanding of the Past (University of York), and the School of Classics/the Scottish Hellenic Society at the University of St Andrews. 


\section{References}

Alcalde, Á. (2018). Spatializing transnational history: European spaces and territories. European Review of History 25(3-4), 553-567.

Atkinson, R. (2015). Losing One's Place: Narratives of Neighbourhood Change, Market Injustice and Symbolic Displacement. Housing, Theory and Society 32(4), 373-388.

Casey, E. S. (2001). Between Geography and Philosophy: What Does It Mean to Be in the Place-World? Annals of the Association of American Geographers 91(4), 683-693.

Confino, A. (1987). The Nation as a Local Metaphor: Wurttemberg, Imperial Germany, and National Memory, 1871-1918. Chapel Hill: University of North Carolina Press.

Cosgrove, D., B. Roscoe, and S. Rycroft. (1996). Landscape and Identity at Ladybower Reservoir and Rutland Water. Transactions of the Institute of British Geographers 21(3), 53451.

Cresswell, T. (2004). Place: A Short Introduction. Malden: Blackwell.

Davidson, M. (2009). Displacement, Space and Dwelling: Placing Gentrification Debate. Ethics, Place \& Environment 12(2), 219-234.

Certeau, M. de (1984). The Practice of Everyday Life. Berkeley: University of California Press. Doutriaux, S., C. Geisler, and G. Shively. (2008). Competing for Coffee Space: DevelopmentInduced Displacement in the Central Highlands of Vietnam. Rural Sociology 73(4), 528-54.

Farrar, M. E. (2009). Home/Sick: Memory, Place, and Loss in New Orleans. Theory \& Event 12(4).

Feldman, S. and C. Geisler. (2012). Land Expropriation and Displacement in Bangladesh. The Journal of Peasant Studies 39(3-4), 971-993. 
Feldman, S., C. Geisler, and L. Silberling. (2003). Moving Targets: Displacement, Impoverishment, and Development. International Social Science Journal 55(175), 7-13.

Forbes, H. (2007). Meaning and Identity in a Greek Landscape: An Archaeological Ethnography. Cambridge: Cambridge University Press.

Francaviglia, R. V. (1978). Xenia Rebuilds: Effects of Predisaster Conditioning on Postdisaster Redevelopment. Journal of the American Institute of Planners 44(1), 13-24.

Di Giovine, M. and R. Brulotte. (2014). Introduction: Food and Foodways as Cultural Heritage. In R. Brulotte and M. Di Giovine (eds). Edible Identities: Food as Cultural Heritage. Farnham: Ashgate, 1-28.

Halstead, P. (1989). Book reviews - Paul Bahn. Bluff your way in archaeology. Antiquity, 63(241), 851-853.

Halstead, P. (2014). Two Oxen Ahead: Pre-Mechanized Farming in the Mediterranean. Chichester: John Wiley \& Sons.

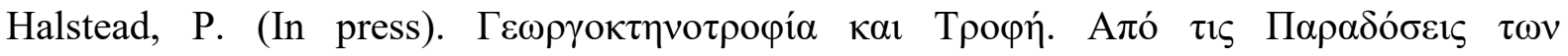

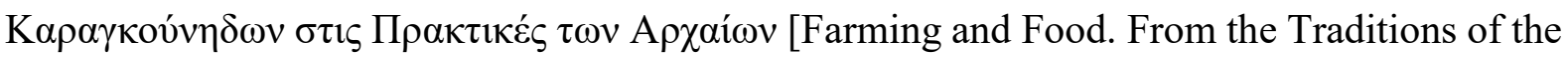
Karagkoúnides to the Practices of the Ancients]. In V. Koziou (ed). Praktika $5 o \Delta l \varepsilon \theta v \varepsilon ́ \varsigma$

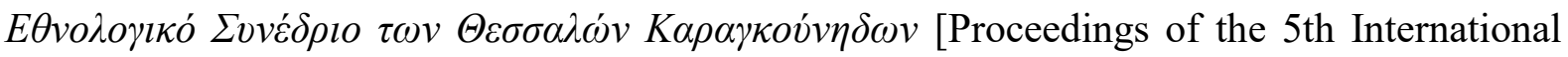
Ethnological Conference of the Thessalian Karagkoúnides].

Hummon, D. (1992). Community Attachment: Local Sentiment and Sense of Place. In I. Altman and S. M. Low (eds). Place Attachment. New York: Plenum Press, 253-278.

Idol, D. (2018). The "Peaceful Conquest" of Lake Kopaïs: Modern Water Management and Environment in Greece. Journal of Modern Greek Studies 36(1), 71-95. 
Jürgenson, A. (2015). Between Landscapes: Migration as Rupture and its Expression in the Landscape. In H. Sooväli-Sepping, H. Reinert, and J. Miles-Watson (eds). Ruptured Landscapes: Landscape, Identity and Social Change. New York; London: Springer, 111-130. Kaufman, N. (2009). Place, Race, and Story: Essays on the Past and Future of Historic Preservation. Abingdon: Routledge.

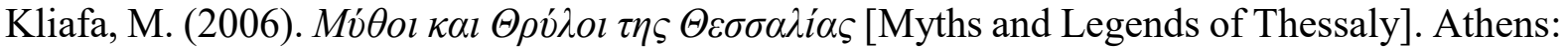
Kedros.

Knight, D. (2012). Cultural Proximity: Crisis, Time and Social Memory in Central Greece. History and Anthropology 23(3), 349-74.

Krahtopoulou, N., H. Orengo, K. Palaiochoritis, and A. Stamati. (In press). Av $\alpha \delta \alpha \sigma \mu$ ó $\varsigma\rceil\rceil \varsigma$

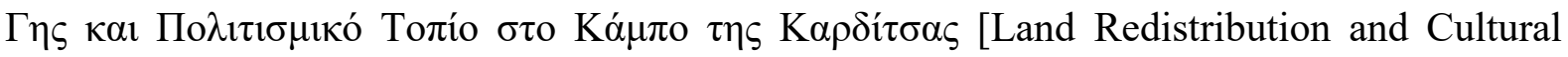
Landscape in Kambos, Karditsa]. AETHSE 5.

Lefebvre, H. (1991[1974]). The Production of Space. Oxford: Blackwell.

Lekan, T. (2009). Imagining the Nation in Nature: Landscape Preservation and German Identity, 1885-1945. Cambridge, MA: Harvard University Press.

Miles-Watson, J., H. Reinert, and H. Sooväli-Sepping. (2015). Introduction: Ruptured Landscapes. In H. Sooväli-Sepping, H. Reinert, and J. Miles-Watson (eds). Ruptured Landscapes: Landscape, Identity and Social Change. New York: Springer, 1-8.

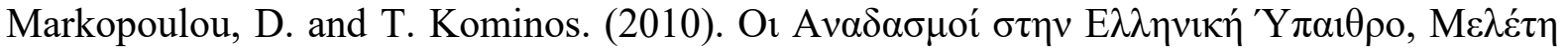

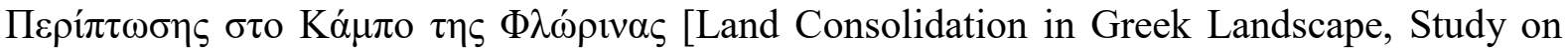
Florina's Plain]. Proceedings of the 9th Pan-Hellenic Geographical Conference of the Hellenic Geographical Society. Athens.

Nixon, L. (2006). Making a Landscape Sacred: Outlying Churches and Icon Stands in Sphakia, Southwestern Crete. Oxford: Oxbow Books. 
Orengo, H., A. Krahtopoulou, A. Garcia-Molsosa, K. Palaiochoritis, and A. Stamati. (2015). Photogrammetric Re-Discovery of the Hidden Long-Term Landscapes of Western Thessaly, Central Greece. Journal of Archaeological Science 64, 100-109.

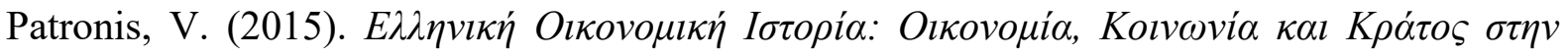

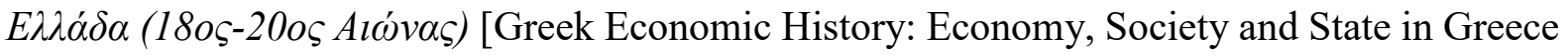
(18th-20th Centuries)]. Athens: Association of Greek Academic Libraries.

Relph, E. (1976). Place and Placelessness. London: Pion.

Riley, R. B. (1992). Attachment to the Ordinary Landscape. In I. Altman and S. M. Low (eds). Place Attachment. New York: Plenum Press, 13-35.

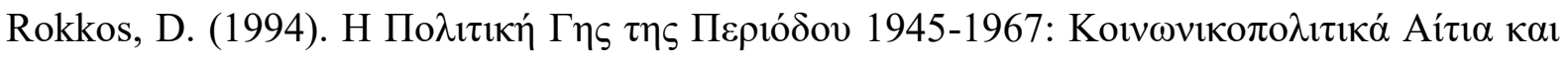

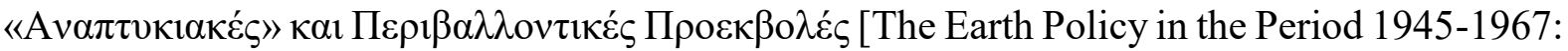
Sociopolitical Causes and "Developmental" and Environmental Impacts]. Proceedings of the 4th Scientific Conference of the Sakis Karagiorgas Foundation, "Greek Society in the First Post-war Period 1945-1967”. Athens, 533-560.

Schlögel, K. (2016). In Space We Read Time. On the History of Civilisation and Geopolitics. Chicago: University of Chicago Press.

Seremetakis, C. N. (1994a). The Memory of the Senses, Part I: Marks of the Transitory. In C. N. Seremetakis (ed). The Senses Still: Perception and Memory as Material Culture in Modernity. Chicago; London: University of Chicago Press, 1-18.

Seremetakis, C. N. (1994b). The Memory of the Senses, Part II: Still Acts. In C. N. Seremetakis (ed). The Senses Still: Perception and Memory as Material Culture in Modernity. Chicago; London: University of Chicago Press, 23-43.

Shaw, K. S. and I. W. Hagemans. (2015). "Gentrification Without Displacement" and the Consequent Loss of Place: The Effects of Class Transition on Low-income Residents of Secure 
Housing in Gentrifying Areas. International Journal of Urban and Regional Research 39(2), $323-341$.

Sooväli-Sepping, H., H. Reinert, and J. Miles-Watson. (eds) (2015). Ruptured Landscapes: Landscape, Identity and Social Change. New York: Springer.

Sutton, D. (2001). Remembrance of Repasts: An Anthropology of Food and Memory. Oxford: Berg.

Sutton, D. and L. Vournelis. (2009). Vefa or Mamalakis: Cooking Up Nostalgia in Contemporary Greece. South European Society and Politics 14(2), 147-66.

Tilley, C. (1994). A Phenomenology of Landscape: Places, Paths, and Monuments. Oxford: Berg.

Tilley, C. (2006). Introduction: Identity, Place, Landscape and Heritage. Journal of Material Culture 11(1-2), 7-32.

Tilley, C. and W. Bennett. (2004). The Materiality of Stone: Explorations in Landscape Phenomenology. Oxford: Berg.

Trubek, A. (2008). The Taste of Place: A Cultural Journey into Terroir. Berkeley: University of California Press.

Turton, D. (2005). The Meaning of Place in a World of Movement: Lessons from Long-term Field Research in Southern Ethiopia. Journal of Refugee Studies 18(3), 258-280.

Van Esterik, P. (2006). From Hunger Foods to Heritage Foods: Challenges to Food Localisation in Lao PDR. In R. Wilk (ed). Fast Food/Slow Food: The Cultural Economy of the Global Food System. Lanham: AltaMira Press, 83-96. 
White, R. (2010). What is Spatial History? Spatial History Lab: Working Paper. Available at:

http://web.stanford.edu/group/spatialhistory/cgi-bin/site/pub.php?id=29 [Accessed on 22

November 2018]. 
Tables

\begin{tabular}{|c|c|}
\hline \multicolumn{2}{|c|}{ Table 1: Study villages } \\
\hline Village & Population (2011) \\
\hline Agios Theódoros & 682 \\
\hline Kapadokikó & 457 \\
\hline Karditsomágoula & 2063 \\
\hline Makrychóri & 822 \\
\hline Myríni & 684 \\
\hline Pródromos & 811 \\
\hline Pýrgos Kieríou & 341 \\
\hline
\end{tabular}




\section{Figure captions}

Figure 1 - Karnomágoula, a surviving magoúla. Photograph Nancy Krahtopoulou.

Figure 2 - "The Eye" (To Máti). Its water is associated with healing properties, and clothes are left by those seeking miraculous intervention for sick loved ones (see the branches and the bag). Author photograph.

Figure 3 - An example of a bridge "marooned" by the anadasmós near the village Gorgovites. Author photograph.

Figure 4 - Kostas in the sesame field. Photograph Nancy Krahtopoulou.

Figure 5 - Sheep posing for photographs in Myrini. These sheep are a crossbreed of the Karagkoúnika sheep and foreign varieties imported for their greater milk yield. Author photograph.

Figure 6 - The metal plate (lamarína) from the gástra (cooking pot) in Barba Kostas' yard, Karditsomágoula. Author photograph.

Figure 7 - Café owner with mallet, Kapadokikó. Author photograph.

Figure 8 - A re-enactment of the processing of wheat by pounding grain with wooden mallets in a stone mortar, Kapadokikó. Author photograph.

Figure 9-Charalampos in Pródromos with his "memento" of home-grown maize ears. Author photograph.

\footnotetext{
${ }^{1}$ The word anadasmós means "redistribution", but is used locally to refer to both the redistribution of fields and the land reclamation.

${ }^{2}$ On the legal basis for voluntary and compulsory redistribution/consolidation of agricultural land, see Rokkos (1994, 173-174).

${ }^{3}$ Large plots of 2.5 ha or more in a single location (which were uncommon) were exempted from the redistribution process (Rokkos 1994, 173).

${ }^{4}$ I was told by a shepherd on the outskirts of Makrychóri that in that village the community also decided to distribute gamma category fields to the landless, allotting acreage according to the size of the family.
} 
${ }^{5}$ In Agios Theódoros, I was told that a group of farmers from that village had in fact already petitioned the Ministry of Agriculture directly to request that the anadasmós take place in their area.

${ }^{6}$ Petros recalled that in Pródromos some of the locals were dismayed, remarking that "if the anadasmós happens, we are ruined!" According to Petros, they sent a delegation to Athens to appeal for the plans to be abandoned.

${ }^{7}$ In the years since the anadasmós, the field system has fragmented again as parcels of land change hands. Thanasis told me that he now has so many small plots of land in so many different places that he requires a special computer program to keep track of them all, "so that I don't lose them!" Many of my informants feel that a new anadasmós is required today.

${ }^{8}$ In Greece as elsewhere, grains have social connotations: whereas finely ground wheat flour is widely considered a wealthy foodstuff, in many places cornbread is considered inedible (P. Halstead 2014, 165, 291). 